\title{
BIOSINTESIS NANOPARTIKEL ZnO MENGGUNAKAN RAGI SACCHAROMYCES CEREVISIAE GALUR A12 DAN KARAKTERISASINYA
}

\author{
A. Fatimah, E. Risky, S. Ishmayana dan D. Rakhmawati Eddy* \\ Departemen Kimia, Fakultas Matematika dan Ilmu Pengetahuan Alam, Universitas Padjadjaran \\ *Email: diana.rahmawati@unpad.ac.id
}

\begin{abstract}
ABSTRAK
$\mathrm{ZnO}$ merupakan material semikonduktor yang memiliki energi celah pita 3,3 eV. Karakteristik ini menyebabkan $\mathrm{ZnO}$ memiliki berbagai macam aplikasi. Nanopartikel $\mathrm{ZnO}$ diketahui memiliki sifat katalitik, fotonik, optoelektronik, penyaring UV, sifat antimikroba, konduktivitas yang baik, juga memiliki stabilitas kimia yang baik. Nanopartikel $\mathrm{ZnO}$ dapat disintesis melalui proses sintesis fisika dan kimia tetapi memiliki beberapa kelemahan seperti membutuhkan suhu dan tekanan tinggi juga penggunaan pelarut yang berbahaya. Biosintesis merupakan cara alternatif untuk menyintesis nanopartikel $\mathrm{ZnO}$ karena prosesnya yang sederhana tidak menggunakan suhu dan tekanan tinggi juga pelarut yang berbahaya. Pada penelitian ini digunakan ragi Saccharomyces cerevisiae galur A12 dan seng asetat dihidrat sebagai prekursor. Hasil sintesis kemudian dikarakterisasi menggunakan spektrofotometer UV-Visibel menujukkan puncak pada daerah $380 \mathrm{~nm}$ sesuai dengan standar $\mathrm{ZnO}$, puncak pada $430 \mathrm{~cm}^{-1}$ yang menunjukkan adanya stretching Zn-O berdasarkan hasil karakterisasi menggunakan Fourier Transform Infrared (FTIR), dan ukuran kristal rata-rata sebesar 37,4 nm berdasarkan karakterisasi menggunakan X-Ray Diffraction (XRD).
\end{abstract}

Kata kunci: biosintesis, nanopartikel, Sacharomyces cerevisiae, $\mathrm{ZnO}$

\begin{abstract}
$\mathrm{ZnO}$ is a semiconductor material that has $3.3 \mathrm{eV}$ energy band gap. This characteristic allows $\mathrm{ZnO}$ to have a variety of applications. Nano size $\mathrm{ZnO}$ is known to have catalytic, photonic, optoelectronic, antimicrobial, and UV filtering properties. It also has good conductivity and chemical stability. ZnO nanoparticles can be synthesized through physical and chemical synthesis method, which require extreme condition such as high temperature, high pressure and toxic solvents. Biosynthesis becomes an alternative for $\mathrm{ZnO}$ nanoparticles synthesis because it can be synthesized simply without extreme condition. . In the present study, ZnO nanoparticles biosynthesis was carried out using Sacharomyces cerevisiae yeast A12 strain and zinc acetate dihydrate as precursors. The product were then characterized using UV-Visible spectrophotometer anda peak at $380 \mathrm{~nm}$ was observed, indicating a characteristic peak for $\mathrm{ZnO}$, while Fourier Transform Infrared (FTIR) indicated a peak at $430 \mathrm{~cm}^{-1}$ correspond to $\mathrm{Zn}-\mathrm{O}$ stretching. Based on X-ray diffraction (XRD) method, the average crystal size was $37.4 \mathrm{~nm}$.
\end{abstract}

Keywords: biosynthesis, nanoparticles, Sacharomyces cerevisiae, $\mathrm{ZnO}$

\section{PENDAHULUAN}

Seng oksida dikenal sebagai
semikonduktor II-VI karena Zn dan O
merupakan golongan II dan VI dalam
sistem periodik unsur. ZnO memiliki band
gap yang luas, yakni sebesar $3,3 \mathrm{eV}$ dan
energi ikat eksiton sebesar $60 \mathrm{meV}$ pada
suhu ruangan. Hal tersebut menyebabkan
ZnO memiliki beberapa karakteristik
seperti sifat optis yang unik, kemampuan
sensor kimia, juga memiliki sifat
piezoelektrik (Sirelkhatim et al., 2015).
Karakteristik tersebut memungkinkan $\mathrm{ZnO}$ untuk menjadi bahan baku utama dalam bidang elektronik (Hofstetter, 2010), optoelektronik (Djurisic et al., 2010), fotokatalis (Shinde et al., 2016), hingga biomedis (Zhu et al., 2016).

Material nano dengan berbagai bentuk dan ukuran telah menarik banyak perhatian karena sifat fisikokimianya yang lebih unik dibandingkan dengan material dengan ukuran yang lebih besar, misalnya nanopartikel $\mathrm{ZnO}$ yang memiliki aktivitas antibakteri, antijamur, menyaring sinar UV, 
dan aktivitas fotokimia juga katalitik yang tinggi (Jayaseelan et al., 2012).

Sintesis nanopartikel dapat dilakukan dengan proses kimia, fisika, dan biologis. Biosintesis dapat menjadi alternatif sintesis nanopartikel, termasuk nanopartikel $\mathrm{ZnO}$, yang ramah lingkungan karena proses biosintesis tidak menggunakan pelarut toksik, suhu dan tekanan yang tinggi ataupun proses refluks yang lama (Chauhan et al., 2015). Mikroorganisme yang dapat digunakan untuk melakukan biosintesis diantaranya jamur, ragi, tanaman, dan alga (Moghaddam et al., 2017).

Saccharomyces cerevisiae merupakan ragi yang sangat baik digunakan untuk produksi bahkan pada skala komersial dari molekul biologis karena kapasitas fermentasi yang tinggi dan berstatus sebagai organisme yang aman ditambahkan pada makanan (Apel et al., 2017). Oleh karena itu pada penelitian ini dilakukan biosintesis nanopartikel $\mathrm{ZnO}$ menggunakan ragi $S$. cerevisiae galur A1.

\section{MATERI DAN METODE}

\section{Bahan}

Bahan yang menjadi objek penelitian ini adalah seng asetat dihidrat, Saccharomyces cerevisiae galur A12, bacteriological peptone, D-glukosa, kalium dihidrogen fosfat, amonium sulfat, yeast extract, dan air suling. Semua bahan yang digunakan memiliki kualitas proanalis.

\section{Peralatan}

Alat yang digunakan dalam penelitian ini adalah alat-alat gelas, autoclave (Prestige Medical Series 2100), sentrifugator (Beckman Model TJ-6), shaker (Wisd), spektrofotometer UV-Vis (Genesys 10S), FTIR, dan XRD (PANalytical X'Pert PRO seri PW3040/X0).

\section{CARA KERJA}

Kultur inokulum dibuat dengan menumbuhkan $S$. cerevisiae A12 pada media yeast extract-peptone (YEP) yang mengandung $2 \%$ glukosa sebanyak $10 \mathrm{~mL}$. Kultur ditumbuhkan selama 18 jam. Kemudian sebanyak $5 \mathrm{~mL}$ kultur inokulum dipindahkan pada media pertumbuhan sel dengan volume $100 \mathrm{~mL}$. Kultur ditumbuhkan dengan kecepatan pengocokan $180 \mathrm{rpm}$ selama 24 jam. Kemudian kultur disentrifugasi dengan kecepatan $1500 \mathrm{rpm}$ selama 30 menit untuk memisahkan sel dan media. Media yang diperoleh digunakan untuk biosintesis nanopartikel $\mathrm{ZnO}$.

Sebanyak $1,1 \mathrm{~g}$ seng asetat dihidrat ditambahkan ke dalam $50 \mathrm{~mL}$ supernatan hasil sentrifugasi dan dilakukan inkubasi selama 48 jam. Nanopartikel yang terbentuk dipisahkan dengan sentrifugasi pada kecepatan 10.000 rpm dan dikeringkan pada suhu $150^{\circ} \mathrm{C}$ selama 6 jam. Nanopartikel yang sudah kering dikarakterisasi dengan spektrofotometer UVVis, FTIR dan XRD.

\section{HASIL DAN PEMBAHASAN}

\section{Peremajan kultur ragi Saccharomyces cerevisiae galur A12}

Kultur ragi $S$ cerevisiae galur A12 ditumbuhkan dalam media cair yeast extract peptone (YEP). Media YEP ini mengandung ekstrak ragi, bacto peptone, D-glukosa, amonium sulfat, dan kalium dihidrogen fosfat, yang menjadi sumber karbohidrat, nitrogen, vitamin, dan mineral yang berperan pada pertumbuhan ragi. Sel ragi dibiakkan pada media YEP dan diinkubasi selama 24 jam sambil diaduk menggunakan shaker dengan kecepatan $180 \mathrm{rpm}$. Setelah waktu inkubasi selesai diketahui bahwa ragi telah berhasil ditumbuhkan pada media melalui pengamatan menggunakan mikroskop seperti ditunjukkan pada Gambar 1.

\section{Biosintesis nanopartikel ZnO}

Sel ragi $S$. cerevisiae galur A12 yang telah berhasil ditumbuhkan kemudian disentrifugasi selama 30 menit dengan kecepatan $2.000 \mathrm{rpm}$ untuk dapat memisahkan sel dengan metabolit yang diekskresikan oleh sel tersebut dan digunakan untuk melakukan biosintesis ekstraseluler. Pada biosintesis ekstraseluler ini proses pemisahan nanopartikel yang disintesis dengan sel yang digunakan akan lebih mudah sehingga nanopartikel hasil sintesis lebih murni karena tidak adanya interaksi dengan komponen sel. Supernatan hasil sentrifugasi kemudian ditambahkan dengan 1,1 gram seng asetat dihidrat dan diinkubasi selama 48 jam sambil diaduk menggunakan shaker dengan kecepatan $200 \mathrm{rpm}$. terbentuknya partikel halus berwarna putih menandakan nanopartikel $\mathrm{ZnO}$ telah 
terbentuk. Nanopartikel $\mathrm{ZnO}$ terbentuk karena adanya interaksi antara gugus hidroksil yang $\mathrm{Zn}^{2+}$ setelah garam seng astetat dihidrat mengalami reaksi hidrolisis membentuk $\mathrm{Zn}^{2+}$ dan $2 \mathrm{CH}_{3} \mathrm{COO}^{-}$(Moghaddam et al., 2017). Asam amino berperan sebagai capping agent dan akan mencegah agregasi sehingga nanopartikel $\mathrm{ZnO}$ menjadi stabil dengan cara membungkus nanopartikel ZnO (Tarafdar, J.C and Raliya, R., 2013). Nanopartikel ZnO yang dihasilkan kemudian dipisahkan dengan cara

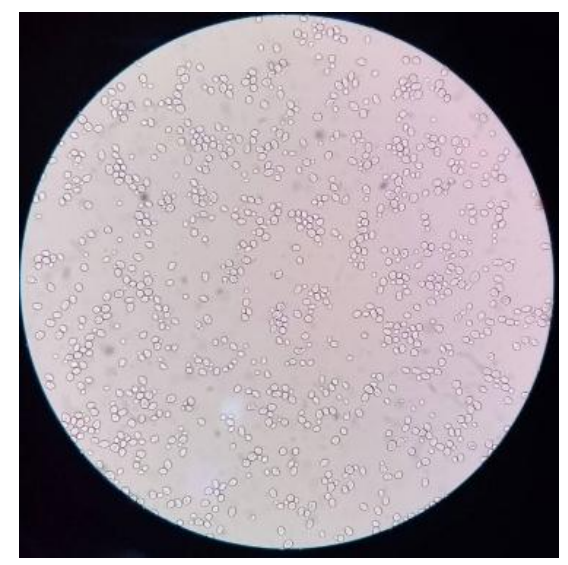

Gambar 1 Sel ragi Sacharomyces cerevisiae galur A12 hasil pengamatan menggunakan mikroskop

\section{Karakterisasi}

\section{Spektrofotometer UV-Visibel}

Nanopartikel $\mathrm{ZnO}$ hasil sintesis dikarakterisasi menggunakan spektrofotometer UV-Visibel, dan hasilnya ditunjukkan pada Gambar 2. Hasil karakterisasi menunjukkan adanya puncak pada $380 \mathrm{~nm}$ menandakan nanopartikel $\mathrm{ZnO}$ telah terbentuk (Jayaseelan et al., 2012).

\section{Fourier Transform Infrared (FTIR)}

Hasil karakterisasi menggunakan FTIR (Gambar 3) menunjukkan puncak yang lebar pada $3.000-3.600 \mathrm{~cm}^{-1}$ yang menunjukkan adanya gugus $-\mathrm{OH}, \mathrm{N}-\mathrm{H}$, dan aromatik, 1.650 $\mathrm{cm}^{-1}$ menujukkan adanya gugus $\mathrm{C}=\mathrm{O}$. Gugusgugus tersebut berasal dari media pertumbuhan ragi atau enzim ragi yang masih menempel, dan 400-600 $\mathrm{cm}^{-1}$ menunjukkan adanya stretching $\mathrm{Zn}-\mathrm{O}$ (Sangeetha et al., 2011). bermuatan negatif dari asam amino dengan ion

disentrifugasi selama 10 menit dengan kecepatan $10.000 \mathrm{rpm}$ lalu dibilas dengan akuades untuk menghilangkan asetat dan media pertumbuhan ragi yang masih menempel. Kemudian endapan dikeringkan dalam oven selama 6 jam pada suhu $150^{\circ} \mathrm{C}$ untuk menghilangkan pelarut sehingga didapatkan serbuk nanopartikel $\mathrm{ZnO}$.

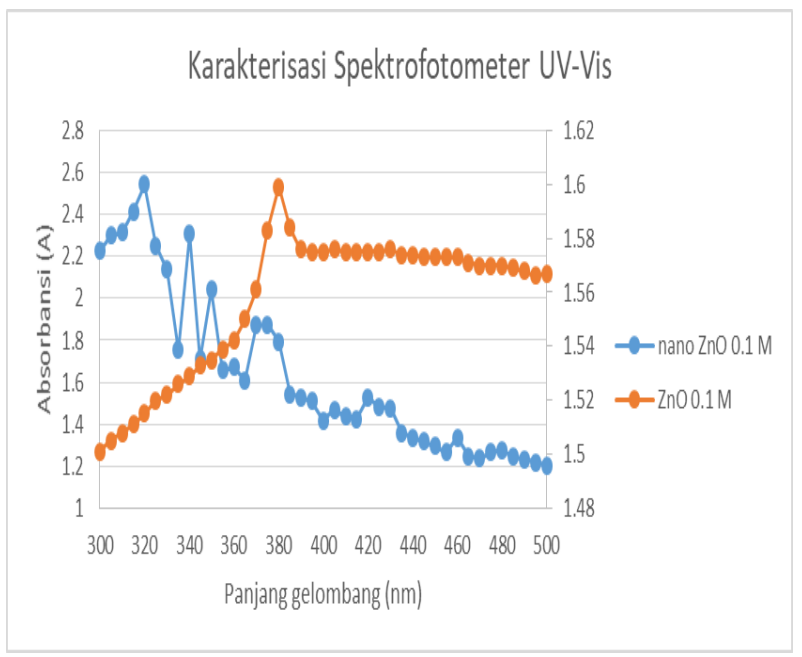

Gambar 2 Hasil karakterisasi larutan $\mathrm{ZnO}$ dan nanopartikel $\mathrm{ZnO}$ hasil biosintesis spektrofotometer UV-Visibel

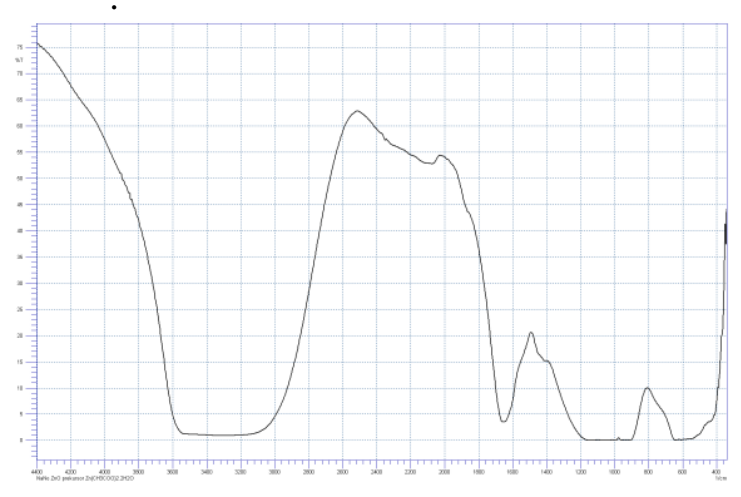

Gambar 3 Hasil karakterisasi nanopartikel $\mathrm{ZnO}$ hasil biosintesis menggunakan FTIR 


\section{X-Ray Diffraction (XRD)}

Hasil karakterisasi XRD (Gambar 4) menunjukkan nanopartikel $\mathrm{ZnO}$ telah berhasil disintesis namun dengan kristalinitas yang rendah, hal ini dapat disebabkan karena masih adanya pengotor. Dari hasil XRD ini juga dapat diketahui ukuran kristal dengan menggunakan persamaan Scherer yaitu sebesar $37,4 \mathrm{~nm}$. Puncak karakteristik nanopartikel $\mathrm{ZnO}$ sesuai dengan puncak standard ICSD 98003-1060.
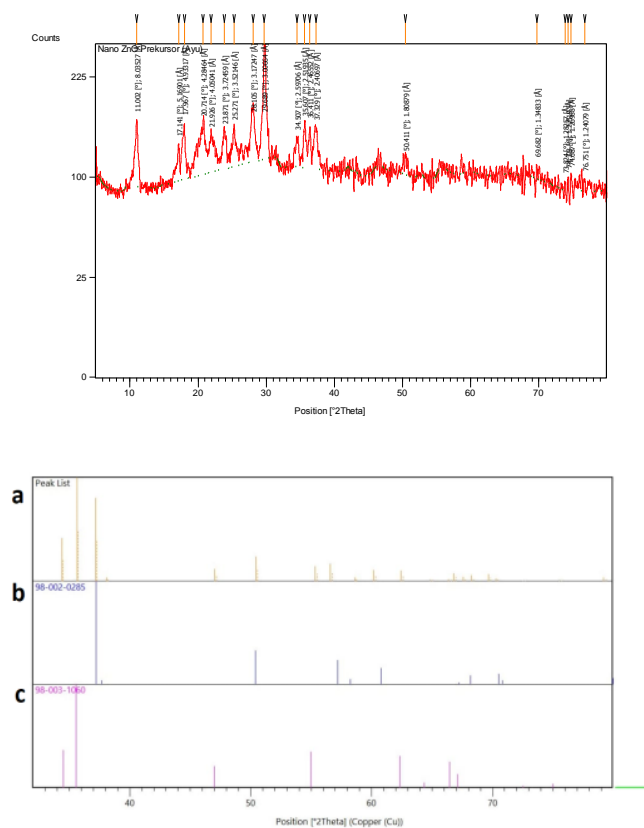

Gambar 4 Hasil karakterisasi nanopartikel $\mathrm{ZnO}$ hasil biosintesis menggunakan XRD, puncak sampel nanopartikel $\mathrm{ZnO}$ hasil sintesis (a), standard ICSD $\mathrm{Zn}(\mathrm{OH})_{2}$ (b), standard ICSD $\mathrm{ZnO}$ (c)

\section{SIMPULAN DAN SARAN}

\section{Simpulan}

Nanopartikel $\mathrm{ZnO}$ berhasil disintesis menggunakan ragi S. cerevisiae galur A12 dan diketahui memiliki ukuran kristal rata-rata $37,4 \mathrm{~nm}$

\section{Saran}

Untuk mendapatkan nanopartikel $\mathrm{ZnO}$ dengan kristalinitas tinggi biosintesis seharusnya dilakukan pada suhu optimum yaitu $37^{\circ} \mathrm{C}$ atau dengan menambah waktu inkubasi menjadi lebih lama.

\section{UCAPAN TERIMAKASIH}

Penulis mengucapkan terimakasih kepada Kementrian Riset, Teknologi, dan Pendidikan Tinggi Republik Indonesia yang telah mendanai penelitian ini, juga Departemen Kimia, Fakultas Matematika dan Ilmu Pengetahuan Alam, Universitas Padjadjaran.

\section{DAFTAR PUSTAKA}

Apel, A. R., d'Espaux, L., Wehrs, M., Sachs, D., Li1, R. A., Tong, G. J., Garber, M., Nnadi, O., Zhuang, W., Hillson, N. J., Keasling, J, D., and Mukhopadhyay, A., 2017, A Cas9based toolkit to program gene expression in Saccharomyces cerevisiae, Nucleic Acids Research, 45(1): 496-508.

Chauhan, R., Reddy, A. and Abraham, J., 2015, Biosynthesis of silver and zinc oxide nanoparticles using Pichia fermentans JA2 and their antimicrobial property, Applied Nanoscience, 5(1): 63-71.

Djurisic, A. B., Ng, A. M. C., Chen, X. Y., 2010, ZnO nanostructures for optoelectronics: Material properties and device applications, Progress in Quantum Electronics, 34: 191-259.

Hofstetter, D., 2010, ZnO Devices and Applications: A Review of Current Status and Future Prospects, Proceedings of the IEEE, 98(7): 12551263

Jayaseelan C, Rahuman AA, Kirthi AV, Marimuthu S, Santhoshkumar T, Bagavan A, Gaurav K, Karthik L, Rao KVB., 2012, Novel microbial route to synthesize $\mathrm{ZnO}$ nanoparticles using Aeromonas hydrophila and their activity against pathogenic bacteria and fungi., Spectrochimica Acta Part A: Molecular and Biomolecular Spectroscopy, 90: 78-84

Moghaddam, A. B., Moniri, M., Azizi, S., Rahim,R. A., Ariff, A. B., Saad, W. Z., Namvar, F., Navaderi, M., Mohamad, R., 2017, Biosynthesis of $\mathrm{ZnO}$ nanoparticles by a new Pichia kudriavzevii yeast strain and 
evaluation of their antimicrobial and

Sangeetha, G., Rajeshwari, S., Venckatesh, R., 2011, Green synthesis of zinc oxide nanoparticles by aloe barbadensis miller leaf extract: Structure and optical properties, Materials Research Bulletin., 46: 2560-2566.

Sirelkhatim, A., Mahmud, S., Seeni, A., Kaus, N. H. M., Ann, L. C., Bakhori, S. J. M., Hasan, H., Mohamad, D., 2015, Review on zinc oxide nanoparticles: Antibacterial activity and toxicity mechanism, Nano-Micro Letters, 7(3): 219-242. antioxidant activities, Molecules. 22: 6

Suchea, M. and Tudose, 2016, ZnO for Photocatalytic air purification applications $\mathrm{ZnO}$ for photocatalytic air purification applications, International Conference on Innovative Research, 133: 0-7

Zhu, P., Weng, Z., Li, X., Liu, X., Wu, S., Yeung, K,W,K., Wang, X., Cui, Z., Yang, X., Chu, P, K., 2016, Biomedical Applications of Functionalized $\mathrm{ZnO}$ Nanomaterials: from Biosensors to Bioimaging, Advanced Material 3: 1-30 